[Vicino Oriente XXIII (2019), pp. 139-153]

\title{
EXCAVATIONS AT ISTAKHR IN 2012: A DEEP STRATIGRAPHICAL INSIGHT*
}

\author{
Laura Ebanista - Sapienza University of Rome
}

This paper deals with the matrix of the excavation carried out in 2012 at Istakhr, west of the site of the mosque. The results of the archaeological campaign, already published, are integrated here with the matrix in order to highlight stratigraphic unit relationships and clarify the succession of the phases.

Keywords: Istakhr; Iran; excavation; matrix; Islamic period

During the second archaeological campaign of the joint Iranian-Italian Archaeological Mission at Istakhr, ${ }^{1}$ in the autumn 2012, the area west of the site of the mosque was investigated by digging a trench. ${ }^{2}$ The digging area was selected after the first campaign in the spring of 2012 when an archaeological survey was carried out and a DTM of the area west of the site of the mosque was produced. ${ }^{3}$ A linear depression parallel to the West Wall was observed, ${ }^{4}$ and after the excavation the depression was found to correspond to a paved street (WSU 131-203, SU 163-152-159) and a sewer below WSU 182. Furthermore, a trace of vegetation, connected with an opening in the West Wall, was detected. ${ }^{5}$

As the Iranian counterpart requested, extensive digging was not allowed, so the team opened several tests which were later unified into a single trench with a narrow and elongated shape. The latter (figs. 1-2) was oriented E-W and measured $20.90 \times 2 \mathrm{~m}$, with an extension of 4.50 to $4.90 \mathrm{~m}$ close to the west wall of the 'mosque', identified by Whitcomb as the qibli wall, namely the West Wall. ${ }^{6}$

\section{PHASE 9}

The excavation area was completely covered by humus (SU 101), which also covered the structure of the 'mosque' (WSU 1-2-7) by a few centimetres on the east side of the trench. ${ }^{7}$

On the west side of the trench, SU 101 filled several plough traces (from the east SU $126,-127,-128,-103,-104,-105,-106,-107,-108,-109)$ dating to a very recent past but

* This paper is a systematic stratigraphic analysis on matrix, not published in Fontana 2018. For the phases see Jaia 2018 and Ebanista 2018.

1 The mission was directed, on the Italian side, by Maria Vittoria Fontana. I am grateful to her for the opportunity to study this interesting archaeological context. The excavation was conducted in the field by Ahmad Ali Asadi, Martina Rugiadi, Alessandro M. Jaia, Alessandro Blanco, Valentina Cipollari and the author.

2 For the excavation report see Chegini et al. 2013, and Fontana 2013; see also Fontana et al. 2012 and Fontana et al. 2016. For a more exhaustive discussion about the excavation see Jaia 2018 and Ebanista 2018.

See in particular Fontana et al. 2012.

On the West Wall see below and n. 5 .

See Jaia 2018, 322, fig. 2.

Whitcomb 1979, 367. On the site of the mosque, see Di Cesare - Ebanista 2018.

The site of the mosque was partially investigated during the last century (cf. Fontana 2018; Rugiadi - Colliva 2018; Di Cesare - Ebanista 2018).

ISSN 0393-0300

e-ISSN 2532-5159

Rivista Open Access 
before the present prohibition of cultivation in order to preserve the Istakhr site. Pit SU 111 (filled by SU 110) could also be linked to these modern anthropic activities which covered a rather uniform layer SU $118=113=102$, including very few fragments of pottery and some stones.

On the east side of the trench, SU 118 covered WSU 6, the closing device of the door of the West Wall. All these activities could be connected to phase $9 .^{8}$

\section{PHASE 8}

The rather homogeneous layer SU $118=113=102$ (fig. 2 ) covered a complex sequence of layers related to a re-occupation of the area whose chronology is difficult to indicate. The remains of the walls WSU 147, made of local stone shards and bricks re-used and set without mortar, were unearthed; this wall was founded on WSU 197 and 196. ${ }^{9}$ WSU 147 was covered by several layers of decay of this WSU and related structures, as several bricks and stones testify: SU 112 on the east side, while on the west the area of fire SU 116 (related to a pastoral activity?) covered SU 124 and 129. Close to the east end of WSU 147 an irregularly shaped pit SU -144 (approximately $0.90 \mathrm{E}-\mathrm{W} \times 1.00 \mathrm{~N}-\mathrm{S}$, fig. 3) was brought to light; it was filled (SU 142) by several nearly complete wares $\left(10^{\text {th }}-\right.$ early $13^{\text {th }}$ centuries). ${ }^{10}$ It was likely a dump for material, recovered at a later stage, to fill a pit or depression in order to level the floor coeval to WSU 147; pit SU -144 cuts SU 133, a great levelling layer related to phase 7 .

Although there is no reliable stratigraphic connection, the door in the West Wall was probably closed during the same phase by roughly cut limestones joined by the whitish mortar WSU 6, which seems to be founded on the quite compact layer SU $8 .^{11}$

\section{PHASE 7}

A great levelling layer (from west SU $133=114=140$, fig. 2) was detected on the west side of the trench. It was made in order to cover older structures (the recovered pottery testifies a chronology between the $9^{\text {th }}$ - early $13^{\text {th }}$ centuries). ${ }^{12}$ The levelling activity also intended to unify both the levels on the east and west sides of the trench, close to the West Wall door, as a consequence of the sliding of the collapsed materials from the West Wall (WSU 1-2-7) towards the west (SU 135-141-119-125-120, phase 5).

\section{PhASE $6[\mathrm{~A}-\mathrm{C}]$}

The great levelling layer SU $133=114=140$ (fig. 2) in the central area of the trench covered a clear sequence of street levels related to a period when the paved street WSU 131-203, parallel to the West Wall, was in use on its west side only (for a width of $2.05 \mathrm{~m}$ ), bordered by reused slabs. From the top, three levels, covered by both the levelling layer SU 140-114 and SU 138-139, have been recognised: SU 159 (phase 6c), 152 (phase 6b) and

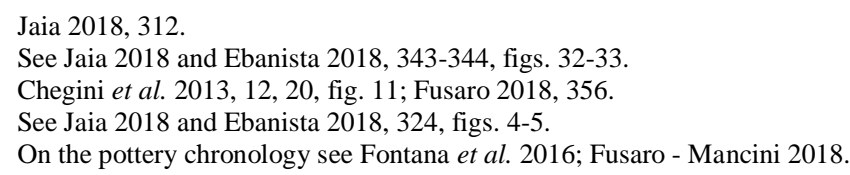


163 (phase 6a, fig. 2). SU 164 was determined in order to keep separate the pottery found just across the street WSU 131-203.

\section{PHASE 5}

The stratigraphy covered by the great levelling SU 118 (Phase 7) on the east side of the trench consisted of several layers sloping towards the west: two great sliding layers SU 135 and 141 (fig. 2), and other layers (SU 119-125-120) related to the same collapse activity (phase 5).

These layers most probably originated from the destruction of the West Wall, as their finds (fragments of stones, clay) would seem to attest. A grey stone element belonging to a Persepolitan-style capital came from SU $141 .^{13}$ The accumulation of material, in particular SU 141, covered the east side of paved street WSU 131. The chronology of the materials recovered spans the $11^{\text {th }}$ and $12^{\text {th }}$ centuries. $^{14}$

\section{PHASE 4}

SU 141 covered two tannūr abandoned close to the door of the West Wall, ${ }^{15}$ one is just east of WSU 7, and completely excavated (SU -178 and 179), and one is south-west of WSU 2 (SU -189 and 185), just partially excavated as it is at the edge of the trench. The pottery from tannūr is datable to the $11^{\text {th }}$ century. ${ }^{16}$ This was probably the moment when the mosque site was destroyed and abandoned.

\section{PhASE $3-3 \mathrm{~A}$}

In the central area of the trench, corresponding to the free area in phases 1-2 between the paved street WSU 131-203 and the western block WSU 196-155, a room was brought to light. ${ }^{17}$ It is defined by WSU 115 (N-S oriented) and 197 (E-W oriented, fig. 1). WSU 115 (thickness $0.63 \mathrm{~m}$ ), covered by SU 114 (fig. 2), is composed of shards of local stone of different sizes and irregular cuts, mostly reused. A stone slab inserted into the wall (fig. 4a) is similar to the slabs used to narrow the street SU 159-152-163 (fig. 4b). The large foundation pit SU -204 was produced in order to build WSU 115 (fig. 4a-b). ${ }^{18}$ On the east side the pit cuts the remake of the street WSU 203. The most reliable layer for dating the wall WSU 115 is SU $165,{ }^{19}$ i.e. the filling of the foundation pit containing pottery datable to the $10^{\text {th }}$ century. ${ }^{20}$ On the west side the foundation pit SU -149 cuts SU $150-151^{21}-160$, and it is filled by SU 148. WSU 197, supported by WSU 115, is $0.54-55 \mathrm{~m}$ wide; in addition it is slightly misaligned (towards the south-east) compared to other buildings. This wall, covered by SU 133 (= SU 114, fig. 2), is also made of shards of local stone (in many cases

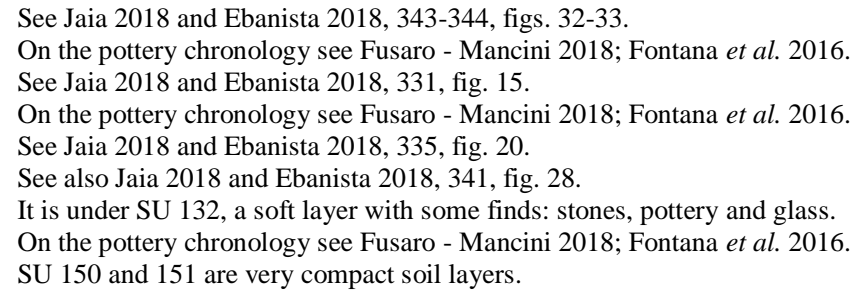


wedge-shaped). Due to the lack of any kind of binder for both the walls, it is possible to hypothesise that the upper part of the building was built in mud-bricks or, more probably, in pisé. The stratigraphic context inside the room defined by SU 115 and 197 is rather complex, where the in-depth test SU 160 (fig. 5) ${ }^{22}$ was carried out on the east side in order to investigate the foundation pit SU -207 of the northern wall WSU 197. Along the west side, SU 160 corresponds to three SU: ${ }^{23}$ SU 200, i.e. the levelling layer (clean and almost inclusion-free soil), SU 201, i.e. the surface of that levelling layer (this could be considered the first-floor layer related to WSU 197) and SU $199,{ }^{24}$ a second levelling layer, which covers both the previous SU (fig. 5). ${ }^{25}$ Pottery found in these layers related to the wall WSU 115 and 197 can be dated to the $11^{\text {th }}$ century. ${ }^{26}$

On the west side of the trench, just east of the room defined by WSU 155 and 196, covered by SU $198,{ }^{27}$ in turn covered by the levelling SU $133(=140=114)$, the narrow wall WSU 154 (width $0.48 \mathrm{~m}, \mathrm{~N}-\mathrm{S}$ oriented), located just east of WSU 155, was brought to light. ${ }^{28}$ It was built with shards of local stone set without mortar (as WSU 115 and 197) and is probably relate to a room built in the free area between the street and the west block which determines a narrow passage between WSU 155 and 154 (phase 3A).

\section{Phase $1-2 \mathrm{~A}$}

In the east area of the trench ${ }^{29}$ the West Wall ${ }^{30}$ is the oldest element, ${ }^{31}$ identified by Whitcomb as the qibli wall, ${ }^{32}$ and consists of WSU 7 (north of the opening closed by WSU 6 ), ${ }^{33}$ WSU 1 (just south of the opening), and WSU 2 (south tower). It is rather thick (1.82 $\mathrm{m}$ ) and is preserved for a maximum height of $1.20 \mathrm{~m}$. The facing is made up of shards of local stone of different sizes, joined with small amounts of mortar; the core of the wall is built in concrete with small stone elements. The excavation of a test, close to the opening in the West Wall, brought to light the threshold of the door WSU 195, built in the very compact layer SU 194, covered by SU 141. A limited test near the threshold identified the red soil with mortar and pottery SU 193, covered by SU 194.

In the western part of the trench ${ }^{34}$ the main block to the west of the mosque site ${ }^{35}$ was brought to light just for a small portion, the eastern corner of a room defined by WSU 196 (E-W oriented) and WSU 155 (N-S oriented), parallel to the West Wall (WSU 1-7). WSU

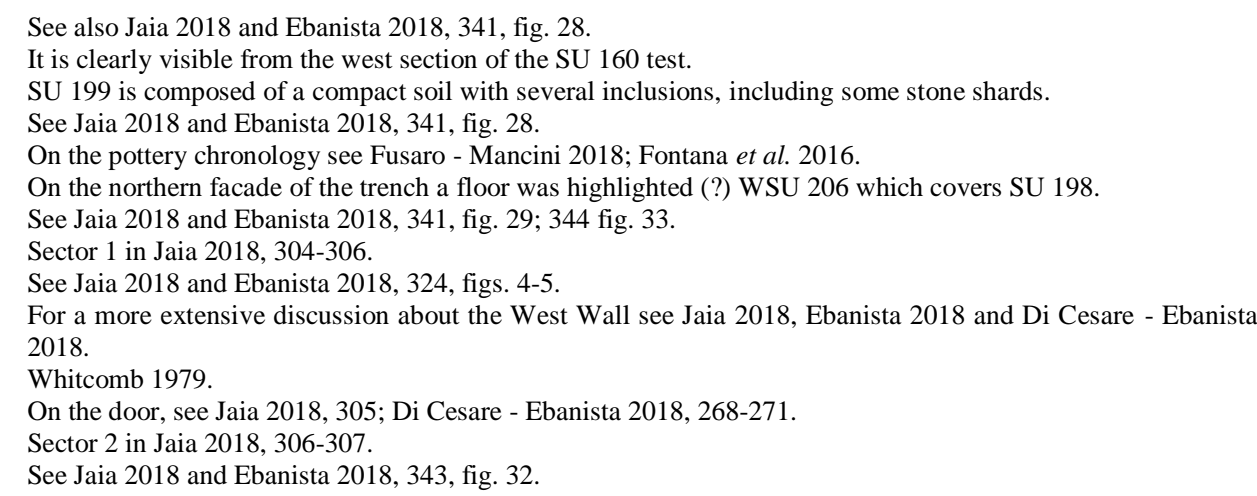


196 is the most preserved wall. It is built with both local stones, set in a very compact way, and quadrangular baked bricks (0.20-0.22 per side) set with good mortar. ${ }^{36}$ During phase 8 WSU 196 was used as the foundation for the wall WSU 147. WSU 155, built in shards of local stone, leans against wall WSU 196. Only a small portion of the inner part of the building (room?) ${ }^{37}$ was excavated due to the limited dimensions of the trench. The concrete ground level SU 168-169 was brought to light, covered by SU 198 (the levelling layer following the abandonment of both the floor levels and the walls 196 and 155 - phase 3), SU 161 (the filling of the pit SU -162) and 158, which can be attributed to the abandonment of the room. It is composed of cementitious conglomerate mixed with minced ceramic sherds and could be considered the floor preparation of the west room defined by WSU 196 and 155 . The pottery found can be dated to the $10^{\text {th }}$ century at the latest. ${ }^{38}$

Despite the limited size of the excavation in the western corner of the trench, it is significant that the height of the concrete floor (whose preparation is constituted by SU 168 and 169) is the same as the door threshold WSU 195 of the West Wall.

In the middle area of the trench, ${ }^{39}$ between the West Wall WSU 1-7 and the western block WSU 155-196, covered on its eastern side by SU 141 (phase 5) and on its western side by the sequence of levels SU 159-152-163-164 of use of the street (phase 6), the large paved street WSU 131, N-S oriented, was unheated (preserved width of $4.67 \mathrm{~m}$ ). ${ }^{40} \mathrm{In}$ its $1^{\text {st }}$ phase the street (re-constructible width of approximately $6.25 \mathrm{~m})^{41}$ was paved with local stone slabs (0.21-0.25 m per side) oriented S-SW/N-NE. ${ }^{42}$ On the east side of the paved surface soil slumping was recognised under a layer composed of large fragments of slabs and shards (SU 180), ${ }^{43}$ which can be interpreted as the collapse of the street on its east side. The removal of the layer unearthed the sewer WSU 182 ( $0.36 \mathrm{~m}$ wide and $0.41 \mathrm{~m}$ high), built of concrete material and coated with mortar. ${ }^{44}$ The water flowed southwards (inclination: $2.2 \%$ ). On its southern side a large fragment of the cover of the sewer, made of local stones put in place dry, is preserved. The filling of the sewer is composed of a very compact clayey material with only a few ceramic fragments (SU 184), covered by a clayey layer with a few ceramic fragments related to a period following the abandonment of the infrastructure SU 183. The few materials found in the two layers are datable to the $9^{\text {th }}-10^{\text {th }}$ centuries. $^{45}$

\footnotetext{
The backed bricks are above all in the upper part of the wall.

See Jaia 2018 and Ebanista 2018, 341, fig. 29.

On the pottery chronology see Fusaro - Mancini 2018; Fontana et al. 2016.

Sector 3 in Jaia 2018, 307-308.

See Jaia 2018 and Ebanista 2018, 344, fig. 34.

See Jaia 2018, 307-308.

4 The orientation is different from that of the contemporary buildings WSU 1-7 and WSU 155-196.

43 This layer is covered by a sequence of layers SU 153,166, 167, 171, -170, 172 in turn covered by SU 140. A sub-quadrangular trench SU -174, covered by SU 141, which covers SU 180, was probably dug in order to remove blocks in a following phase. See Jaia 2018 and Ebanista 2018, 344 fig. 35.

44 See Jaia 2018 and Ebanista 2018, 330-331, figs. 13-14.

45 On the pottery chronology see Fusaro - Mancini 2018; Fontana et al. 2016.
} 
On its west side the paved surface was rearranged twice ${ }^{46}$ after digging SU -202 of the foundation pit for WSU 115 using fragments of the same street and fragments of the same kind of stones (SU -204, WSU 203).

The area between street WSU 131 and western blocks WSU 155 and $196^{47}$ was probably free of buildings in phase 1, at least as far as can be ascertained from the excavated trench. Foundation pit SU -207 of the east-west wall WSU 197 cuts a very compact and smooth clay surface (SU 176, fig. 6), found during the excavation of test SU 160. This level $(0.16-0.22 \mathrm{~m}$, under the street WSU 131 level) is probably the most ancient level of use identified in the trench, preceding the paved street. Half of floor SU 176 is preserved and was in use in phase 1; it was also cut by tannūr SU 188 (diameter $0.92 \mathrm{~m}$ ), and by foundation SU -207. During phase 3 the floor was raised (SU 201) and the tannūr fell out of use, as demonstrated by the filling of pottery fragments in SU 200.

\section{LisT OF SU/WSU ${ }^{49}$}

The stratigraphic units (SU-WSU) follow, together with the excavation date, a short description and the related phase ${ }^{50}$ (see the general excavation matrix, fig. 7).

\begin{tabular}{|c|c|c|c|}
\hline $\begin{array}{l}\text { SU/WSU } \\
\text { NUMBERS }\end{array}$ & $\begin{array}{l}\text { EXCAVATION } \\
\text { DATE (2012) }\end{array}$ & DESCRIPTION & PHASE \\
\hline WSU 1 & 20 October & $\begin{array}{l}\text { Part of the West Wall (thickness 1.82), N-S oriented, just south of the door } \\
\text { (closed with WSU 6) and north of the tower WSU 2. Made up of local stone } \\
\text { elements of different sizes, joined with a thin layer of mortar. }\end{array}$ & Phase 1 \\
\hline WSU 2 & 20 October & $\begin{array}{l}\text { Semi-circular tower (diameter } 1.85 \mathrm{~m} \text { ) of the West Wall, just south of the } \\
\text { door between WSU } 1 \text { and } 7 \text {. Made up of fragments of limestone bound with } \\
\text { very firm white mortar, found more abundantly between stones close to the } \\
\text { façade (west side). It contains a filling of loose materials. }\end{array}$ & Phase 1 \\
\hline SU 3 & 24 October & Greyish layer with mortar and stones, fills SU -4 , covered by SU 118. & Phase 9 \\
\hline SU -4 & 24 October & $\begin{array}{l}\text { Probable pit, approximately round, set in the SE corner of trench. Cuts SU } \\
118 \text {, filled by SU } 3 \text {. }\end{array}$ & Phase 9 \\
\hline WSU 6 & 24 October & $\begin{array}{l}\text { Closing device of the door in the West Wall (between WSU } 1 \text { and 7), } \\
\text { consists of roughly cut limestone joined by whitish mortar, seems to be } \\
\text { founded on SU 8. }\end{array}$ & Phase 8 \\
\hline WSU 7 & 24 October & $\begin{array}{l}\text { Part of the West Wall (thickness 1.82), N-S oriented, just north of the door } \\
\text { (closed with WSU 6). Made up of local stone elements of different sizes, } \\
\text { joined with a thin layer of mortar. }\end{array}$ & Phase1 \\
\hline SU 8 & 24 October & $\begin{array}{l}\text { Clay layer, beige colour, quite compact on which WSU } 6 \text { seems to be } \\
\text { founded. }\end{array}$ & Phase 8 \\
\hline SU 101 & 22 October & Humus covering the whole trench. & \\
\hline SU 102 & 23 October & $\begin{array}{l}\text { Layer of soil with very few pottery sherds and some stones. Covered by SU } \\
101 \text {, cut by SU }-103,-104,-105,-106,-107,-108,-109 \text { and }-111 .=\text { SU } 113-118 \text {. }\end{array}$ & Phase 9 \\
\hline SU -103 & 23 October & Cut of the plough, NW-SE oriented. Covered by SU 101, it cuts SU 102. & Phase 9 \\
\hline SU -104 & 23 October & Cut of the plough, NW-SE oriented. Covered by SU 101, it cuts SU 102. & Phase 9 \\
\hline SU -105 & 23 October & Cut of the plough, NW-SE oriented. Covered by SU 101, it cuts SU 102. & Phase 9 \\
\hline
\end{tabular}

46 See Jaia 2018 and Ebanista 2018, 344, fig. 34.

47 Sector 4 in Jaia 2018, 308-309.

48 The tannū $r$ is filled by SU 188 and covered by SU 186 (an ash layer).

49 SU: stratigraphic unit; WSU: wall stratigraphic unit.

50 See Jaia 2018 


\begin{tabular}{|c|c|c|c|}
\hline \begin{tabular}{l|l|} 
SU/WSU \\
NUMBERS
\end{tabular} & $\begin{array}{l}\text { EXCAVATION } \\
\text { DATE (2012) }\end{array}$ & DESCRIPTION & PHASE \\
\hline SU -106 & 23 October & Cut of the plough, NW-SE oriented. Covered by SU 101, it cuts SU 102. & Phase 9 \\
\hline SU -107 & 23 October & Cut of the plough, NW-SE oriented. Covered by SU 101, it cuts SU 102. & Phase 9 \\
\hline SU -108 & 23 October & Cut of the plough, NW-SE oriented. Covered by SU 101, it cuts SU 102. & Phase 9 \\
\hline SU -109 & 23 October & Cut of the plough, NW-SE oriented. Covered by SU 101, it cuts SU 102. & Phase 9 \\
\hline SU 110 & 23 October & Filling of the pit SU -111. & Phase 9 \\
\hline SU -111 & 23 October & $\begin{array}{l}\text { Irregular-shaped pit, set on the west side of the trench, on its south limit. It } \\
\text { cuts SU } 102 \text {, filled by SU } 110 \text {. }\end{array}$ & Phase 9 \\
\hline SU 112 & 23 October & $\begin{array}{l}\text { Layer of soil with several limestones and bricks in the north corner of the } \\
\text { trench. Covered by SU } 102 \text {. }\end{array}$ & Phase 8 \\
\hline SU 113 & 24 October & $\begin{array}{l}\text { Layer of soil with very few pottery sherds and some stones. Covered by SU } \\
101 \text {, it covers SU } 114=\text { SU } 102-118 \text {. }\end{array}$ & Phase 9 \\
\hline SU 114 & 23 October & Levelling layer with pottery and stones, covered by SU $113=$ SU $133-140$. & Phase 7 \\
\hline WSU 115 & 25 October & $\begin{array}{l}\text { Wall set in the middle of the trench, oriented N-S (thickness } 0.63 \mathrm{~m} \text { ), } \\
\text { composed of shards of local stone of different sizes and irregular cuts. } \\
\text { Covered by SU 114, it fills - SU } 204 \text { and }-149 \text {. }\end{array}$ & Phase 3 \\
\hline SU 116 & 25 October & $\begin{array}{l}\text { Layer of blackish, dusty soil (probably ash), covered by SU 102, it covers } \\
\text { SU } 124 \text {. }\end{array}$ & Phase 8 \\
\hline SU 117 & 25 October & $\begin{array}{l}\text { Layer of soil, west of WSU 115, with some limestone and pottery, covered } \\
\text { by SU } 114 \text {, it covers SU } 122 \text { and } 123 \text {. }\end{array}$ & Phase 2 \\
\hline SU 118 & 25 October & $\begin{array}{l}\text { Layer of soil with very few pieces of pottery and some stones. Covered by } \\
\text { SU } 101 \text {, it covers WSU } 6 \text {, cut by SU }-126,-127,-128=\text { SU } 102-113 \text {. }\end{array}$ & Phase 9 \\
\hline SU 119 & 26 October & $\begin{array}{l}\text { Layer of greyish soil, hard, with small pieces of stones, covered by SU } 118 \text {, } \\
\text { it covers SU } 120 .\end{array}$ & Phase 5 \\
\hline SU 120 & 26 October & $\begin{array}{l}\text { Layer of grey clay with many pottery fragments, glass, iron and bones, } \\
\text { covered by SU 119-125, it covers SU } 135 \text {. }\end{array}$ & Phase 5 \\
\hline SU 121 & 25 October & Layer of light brown soft soil covered by SU 119 and 125, it covers SU 135. & Phase 7 \\
\hline SU 122 & 26 October & $\begin{array}{l}\text { Layer of soil, west of WSU } 115 \text { and south of SU 123, with many blocks of } \\
\text { limestone, bricks and pottery. Covered by SU 117, it covers SU } 130 .\end{array}$ & Phase 2 \\
\hline SU 123 & 26 October & $\begin{array}{l}\text { Layer of soil, west of WSU 115, north of SU } 122 \text { with few bricks and } \\
\text { limestone, covered by SU 117, it covers SU } 130 \text {. }\end{array}$ & Phase 2 \\
\hline SU 124 & 26 October & Layer of soil, west of SU 112, covered by SU 116, it covers SU 129. & Phase 8 \\
\hline SU 125 & 26 October & $\begin{array}{l}\text { Layer of greyish soil, with small pieces of stones, covered by SU 118, it } \\
\text { covers SU } 120 \text {. }\end{array}$ & Phase 5 \\
\hline SU -126 & 26 October & Cut of the plough, NW-SE oriented. Covered by SU 101, it cuts SU 118. & Phase 9 \\
\hline SU -127 & 26 October & Cut of the plough, NW-SE oriented. Covered by SU 101, it cuts SU 118. & Phase 9 \\
\hline SU -128 & 26 October & Cut of the plough, NW-SE oriented. Covered by SU 101, it cuts SU 118. & Phase 9 \\
\hline SU 129 & 26 October & Layer of soil covered by SU 124, it covers SU 133 and WSU 147. & Phase 8 \\
\hline SU 130 & 26 October & $\begin{array}{l}\text { Extremely compact layer of soil with some stones, covered by SU } 122 \text { and } \\
123 \text {, it covers WSU } 131 .\end{array}$ & Phase 2 \\
\hline WSU 131 & 27 October & $\begin{array}{l}\text { Large paved street N-S oriented (preserved width of } 4.67 \mathrm{~m}) \text {. Paved with } \\
\text { local stone slabs }(0.21-0.25 \text { m per side), covered by SU 141, 130, } 180 \text { and } \\
\text { 164. Cut by SU }-202 \text { on the west side. }\end{array}$ & Phase 1 \\
\hline SU 132 & 27 October & $\begin{array}{l}\text { Layer of soft soil, with some stones, pottery and glass, it covers SU 165, fills } \\
\text { SU -204. }\end{array}$ & Phase 3 \\
\hline SU 133 & 27 October & $\begin{array}{l}\text { Levelling layer with large quantity of pottery, covered by SU 129, cut by SU } \\
-144 .=\text { SU } 114-140\end{array}$ & Phase 7 \\
\hline SU 135 & 27 October & $\begin{array}{l}\text { Layer of quite soft grey soil with many pieces of pottery, glass, iron and } \\
\text { bones, covered by SU } 120 \text {, it covers SU 141-146-140. }\end{array}$ & Phase 5 \\
\hline SU 138 & 28 October & $\begin{array}{l}\text { Layer with many limestone blocks (medium and small size), covered by SU } \\
114, \text { it covers SU } 139 .\end{array}$ & Phase 6 \\
\hline SU 139 & 28 October & $\begin{array}{l}\text { Layer with pottery, some glass and bones covered by SU } 114 \text { and SU 138, it } \\
\text { covers SU } 159 .\end{array}$ & Phase 7 \\
\hline
\end{tabular}




\begin{tabular}{|c|c|c|c|}
\hline $\begin{array}{l}\text { SU/WSU } \\
\text { NUMBERS }\end{array}$ & $\begin{array}{l}\text { EXCAVATION } \\
\text { DATE (2012) }\end{array}$ & DESCRIPTION & PHASE \\
\hline SU 140 & 28 October & $\begin{array}{l}\text { Quite hard levelling layer with small pieces of stones, mortar and pottery, } \\
\text { covered by SU } 135=\text { SU } 114-133 \text {. }\end{array}$ & Phase 7 \\
\hline SU 141 & 28 October & Layer of soil covered by SU 135, cut by SU -145 , it covers WSU 131. & Phase 5 \\
\hline SU 142 & 28 October & $\begin{array}{l}\text { Filling of the pit SU }-144 \text {, west of WSU 147, with several nearly complete } \\
\text { vessels. Covered by SU } 129 \text {. }\end{array}$ & Phase 8 \\
\hline SU 143 & 28 October & $\begin{array}{l}\text { Layer of extremely compact soil, with mortar, small stones and pebbles, set } \\
\text { west of WSU } 147 \text {, cut by SU - 144, covered by SU } 129 \text {. }\end{array}$ & Phase 3 \\
\hline SU -144 & 28 October & Pit, it cuts SU 143, filled by SU 142, set west of WSU 147. & Phase 8 \\
\hline WSU 147 & 28 October & $\begin{array}{l}\text { Wall oriented E-W on the western side of the trench made of local stone } \\
\text { shards and bricks set without mortar. Covered by SU 129, it is founded on } \\
\text { WSU } 196 \text { and } 197 \text {. }\end{array}$ & Phase 8 \\
\hline SU 148 & 30 October & Filling of SU -149. & Phase 3 \\
\hline SU -149 & 30 October & $\begin{array}{l}\text { Foundation pit of WSU } 115 \text { on its west side, it cuts SU 150-151-160, filled } \\
\text { by SU } 148 .\end{array}$ & Phase 3 \\
\hline SU 150 & 31 October & $\begin{array}{l}\text { Layer of extremely compact soil with mortar inside, covered by SU 143, it } \\
\text { covers SU } 151 \text {. }\end{array}$ & Phase 3 \\
\hline SU 151 & 31 October & Layer of compact soil, covered by SU 150, it covers SU 199 and 157. & Phase 3 \\
\hline SU 152 & 31 October & $\begin{array}{l}\text { Layer of beige soil, with pebbles and pottery, covered by SU } 159 \text {, it covers } \\
\text { SU } 163 \text {. It could be considered one of the levels of use of the street. }\end{array}$ & $\begin{array}{l}\text { Phase } \\
6 \mathrm{~b}\end{array}$ \\
\hline SU 153 & 31 October & Layer of soil set in the east side of Trench, covered by SU 140, it covers SU 166. & Phase 2 \\
\hline WSU 154 & 1 November & $\begin{array}{l}\text { Wall (width } 0.48 \mathrm{~m} \text { ), N-S oriented, located just east of WSU } 155 . \text { It is built } \\
\text { with shards of local stone set without mortar. Covered by SU } 198 .\end{array}$ & $\begin{array}{l}\text { Phase } \\
3 \mathrm{a}\end{array}$ \\
\hline WSU 155 & 1 November & $\begin{array}{l}\text { Wall set on the west side of the trench, N-S oriented, built with shards of } \\
\text { local stone. Covered by SU 198, it leans against WSU } 196 \text {. }\end{array}$ & Phase 1 \\
\hline SU 156 & 1 November & $\begin{array}{l}\text { Layer of soil between WSU } 154 \text { and WSU 155, covered by SU 198, it covers } \\
\text { SU } 192 .\end{array}$ & $\begin{array}{l}\text { Phase } \\
3 \mathrm{a}\end{array}$ \\
\hline SU 157 & 1 November & $\begin{array}{l}\text { Layer of ash, set in the middle of trench } 1 \text {, east of WSU 154, covered by SU } \\
151 \text {, it covers SU } 160 .\end{array}$ & Phase 3 \\
\hline SU 158 & 1 November & $\begin{array}{l}\text { Layer of soil, set on the West side of the trench, cut by SU }-162 \text {, covered by } \\
\text { SU 161, it covers SU } 168 \text {. }\end{array}$ & Phase 3 \\
\hline SU 159 & 1 November & $\begin{array}{l}\text { Layer of beige soil with small stones, pebbles and pottery, covered by SU } \\
140 \text { and } 114 \text {, it covers SU } 152 \text {. It is one of the levels of use of the street. }\end{array}$ & $\begin{array}{l}\text { Phase } \\
6 \mathrm{c}\end{array}$ \\
\hline $\begin{array}{l}\text { SU } 160 \\
\text { (test) }\end{array}$ & 1 November & $\begin{array}{l}\text { In-depth test conducted on the east side in order to verify the foundation pit } \\
\text { SU }-207 \text { of the wall WSU } 197 \text {. Layer of very compact soil, covered by SU } \\
157 \text {, it covers SU } 176 \text {. }\end{array}$ & Phase 3 \\
\hline SU 161 & 1 November & $\begin{array}{l}\text { Filling of pit SU }-162 \text { set on the west side of the trench, with several bricks. } \\
\text { Covered by SU } 198 \text {. }\end{array}$ & Phase 3 \\
\hline SU -162 & 1 November & Cut set in the west side of the trench, filled by SU 161, it cuts SU 158. & Phase 3 \\
\hline SU 163 & 1 November & $\begin{array}{l}\text { Layer of compact soil, with very few stones and pottery. It was covered by } \\
\text { SU 152, it covers SU 164. It is one of the levels of use of the street. }\end{array}$ & $\begin{array}{l}\text { Phase } \\
6 \mathrm{a}\end{array}$ \\
\hline SU 164 & 2 November & $\begin{array}{l}\text { Layer of soil named to keep separate the pottery just across the street WSU } \\
131 \text {, covered by SU } 163 \text {. }\end{array}$ & $\begin{array}{l}\text { Phase } \\
6 \mathrm{a}\end{array}$ \\
\hline SU 165 & 2 November & $\begin{array}{l}\text { Layer of extremely compact yellowish soil with pottery and bones, covered } \\
\text { by SU 132, it fills SU - } 204 \text {. }\end{array}$ & Phase 3 \\
\hline SU 166 & 2 November & $\begin{array}{l}\text { Layer of soil set on the east side of the trench, east of SU } 164 \text { and 163, } \\
\text { covered by SU } 153 \text {. }\end{array}$ & Phase 2 \\
\hline SU 167 & 2 November & $\begin{array}{l}\text { Layer of soil set on the east side of trench 1, east of SU } 164 \text { and 163, covered } \\
\text { by SU 166, it covers SU } 171 \text {. }\end{array}$ & Phase 2 \\
\hline SU 168 & 2 November & $\begin{array}{l}\text { Compact layer set on the west side of the trench made of cementitious } \\
\text { conglomerate mixed with minced ceramic sherds. Covered by SU 158, it } \\
\text { covers SU } 169 \text {. }\end{array}$ & Phase 1 \\
\hline SU 169 & 2 November & Compact layer set on the west side of the trench made of cementitious & Phase 1 \\
\hline
\end{tabular}




\begin{tabular}{|c|c|c|c|}
\hline \begin{tabular}{l|l} 
SU/WSU \\
NUMBERS
\end{tabular} & \begin{tabular}{|l|} 
EXCAVATION \\
DATE (2012)
\end{tabular} & DESCRIPTION & PHASE \\
\hline & & conglomerate mixed with minced ceramic sherds. Covered by SU 168. & \\
\hline SU -170 & 3 November & $\begin{array}{l}\text { Sub-rectangular pit set on the east side of the trench, it cuts SU 172, filled by } \\
\text { SU } 171 \text {, covered by SU } 167 . \text { Due to its shape, it seems to be the hole made } \\
\text { by the roots of a tree. }\end{array}$ & Phase 2 \\
\hline SU 171 & 3 November & Yellowish soft soil, filling of pit SU -170, covered by SU 167. & Phase 2 \\
\hline SU 172 & 3 November & $\begin{array}{l}\text { Layer of greyish, extremely compact soil, set on the east side of the trench, } \\
\text { cut by SU }-17 \text {, it covers SU } 180 \text {. }\end{array}$ & Phase 2 \\
\hline SU 173 & 3 November & $\begin{array}{l}\text { Filling of SU }-174 \text {, covered by SU } 141 \text { with many pieces of pottery and } \\
\text { bones. }\end{array}$ & Phase 2 \\
\hline SU -174 & 3 November & $\begin{array}{l}\text { Sub-quadrangular cut set west of SU } 175 \text {, covered by SU 141, filled by SU } \\
\text { 173. Trench probably created to remove blocks. }\end{array}$ & Phase 2 \\
\hline SU 175 & 3 November & $\begin{array}{l}\text { Layer of soil with much mortar, east of SU }-174 \text {. Covered by SU 141, it } \\
\text { covers SU } 180 \text {. }\end{array}$ & Phase 2 \\
\hline SU 176 & 3 November & $\begin{array}{l}\text { Very compact clay layer set west of WSU } 115 \text {, covered by SU } 160 \text { (test) and } \\
200 \text {, cut by SU }-207 \text { and }-205 \text {. }\end{array}$ & Phase 1 \\
\hline SU -178 & 4 November & Cut of the tannūr west of WSU 2, covered by SU 141, filled by SU 179. & Phase 4 \\
\hline SU 179 & 4 November & Filling of tannūr SU -178. & Phase 4 \\
\hline SU 180 & 4 November & $\begin{array}{l}\text { Layer composed of large fragments of slabs and shards (collapse of street } \\
\text { WSU 131), covered by SU } 172 \text {. It covers SU } 183 \text {. }\end{array}$ & Phase 2 \\
\hline SU 181 & 4 November & $\begin{array}{l}\text { Layer of soil, east of WSU } 115 \text { and west of WSU 131, covered by SU 165, it } \\
\text { covers SU } 183 \text {. }\end{array}$ & Phase 2 \\
\hline WSU 182 & 4 November & $\begin{array}{l}\text { Sewer }(0.36 \mathrm{~m} \text { wide and } 0.41 \mathrm{~m} \text { high), built in concrete material and coated } \\
\text { with mortar, oriented N-S. The water flowed southwards (incline: } 2.2 \% \text { ). } \\
\text { Covered by SU } 180 \text {, filled by SU } 183-184 \text {. }\end{array}$ & Phase 1 \\
\hline SU 183 & 4 November & $\begin{array}{l}\text { Clayey layer with few ceramic fragments, it fills WSU 182, covered by SU } \\
180 \text {. }\end{array}$ & Phase 2 \\
\hline SU 184 & 4 November & $\begin{array}{l}\text { Very compact clayey material with only a few ceramic fragments, it fills } \\
\text { WSU } 182 \text {, covered by SU } 183 \text {, it covers SU } 184 \text {. }\end{array}$ & Phase 1 \\
\hline SU 185 & 4 November & Filling of tannūr SU -189 on the west side of WSU 2, it fills SU -189. & Phase 4 \\
\hline SU 186 & 4 November & Layer of ash, it covers SU 188, cut by SU -207. & Phase 1 \\
\hline SU 188 & 4 November & $\begin{array}{l}\text { Tannūr set in SU 176, fills SU -205, covered by SU 186, cut by SU }-207 \\
\text { (foundation of wall WSU 197). }\end{array}$ & Phase 1 \\
\hline SU -189 & 4 November & Cut of tannür SU 185. & Phase 4 \\
\hline SU 192 & 6 November & $\begin{array}{l}\text { Hard and compact layer with much pottery, mortar, glass and bricks between } \\
\text { WSU } 154 \text { and } 155 \text {, covered by SU } 156 \text {. }\end{array}$ & $\begin{array}{l}\text { Phase } \\
3 \mathrm{a}\end{array}$ \\
\hline SU 193 & 5 November & Layer of red soil, covered by SU 194, with plaster and mortar inside. & Phase 1 \\
\hline SU 194 & 5 November & $\begin{array}{l}\text { Layer of brown soil, compact, within which the threshold WSU } 195 \text { is built. } \\
\text { Covered by SU 141, it covers SU } 193 \text {. }\end{array}$ & Phase 1 \\
\hline WSU 195 & 6 November & $\begin{array}{l}\text { Threshold of the opening in the West Wall, built of limestone blocks, } \\
\text { covered by SU } 141 \text {. }\end{array}$ & Phase 1 \\
\hline WSU 196 & 6 November & $\begin{array}{l}\text { Wall set in the western corner of the trench, oriented E-W, composed of } \\
\text { elements of local stone and baked bricks set with mortar. Covered by WSU } \\
147 \text {, it leans on WSU } 155 \text {. }\end{array}$ & Phase 1 \\
\hline WSU 197 & 6 November & $\begin{array}{l}\text { Wall (E-W oriented) set in the central area of the trench }(0.54-55 \mathrm{~m} \text { wide) } \\
\text { made of shards of local stone (in many cases wedge-shaped). Covered by SU } \\
133 \text {. }\end{array}$ & Phase 3 \\
\hline SU 198 & 6 November & $\begin{array}{l}\text { Layer of compact soil, set on the west side of the trench covered by SU 133, } \\
\text { it covers WSU 154-155, SU 156-161. }\end{array}$ & Phase 3 \\
\hline \begin{tabular}{|l|} 
SU 199 \\
\end{tabular} & 6 November & $\begin{array}{l}\text { Layer composed of a compact soil with several inclusions, including some } \\
\text { stone shards, visible from the west section of the SU } 160 \text { test. Covered by } \\
\text { SU } 151 \text {, it covers SU } 201 \text {. }\end{array}$ & Phase 3 \\
\hline
\end{tabular}




\begin{tabular}{|l|l|l|l|l|}
\hline $\begin{array}{l}\text { SU/WSU } \\
\text { NUMBERS }\end{array}$ & $\begin{array}{l}\text { EXCAVATION } \\
\text { DATE (2012) }\end{array}$ & DESCRIPTION & PHASE \\
\hline SU 200 & 6 November & $\begin{array}{l}\text { Layer composed of clean and almost inclusion-free soil, visible from the } \\
\text { west section of the SU 160 test, covered by SU 201. }\end{array}$ & Phase 3 \\
\hline SU 201 & 6 November & Surface of the levelling SU 200 (floor), covered by SU 199. & Phase 3 \\
\hline SU -202 & 6 November & $\begin{array}{l}\text { Cut on the western side of WSU 131 made in order to build WSU 115, filled } \\
\text { by WSU 203. }\end{array}$ & Phase 3 \\
\hline WSU 203 & 6 November & $\begin{array}{l}\text { Remake of the street WSU 131 built using fragments of the street and } \\
\text { fragments of the same stone. }\end{array}$ & Phase 3 \\
\hline SU -204 & 6 November & $\begin{array}{l}\text { Foundation pit of WSU 115 on its east side, it cuts WSU 203, filled by SU } \\
165 \text { and 132. }\end{array}$ & Phase 3 \\
\hline SU -205 & 6 November & Cut filled by the tannūr SU 188, covered by SU 186 and cuts SU 176. & Phase 1 \\
\hline WSU 206 & 6 November & Floor (?) visible in the northern section of the trench, it covers SU 198. & Phase 3 \\
\hline SU -207 & 6 November & Foundation pit of WSU 197, it cuts SU 176. & Phase 3 \\
\hline
\end{tabular}

\section{REFERENCES}

Chegini, N.N.Z. - FontanA, M.V. - Asadi, A. - Rugiadi, M. - JAiA, A.M. - Blanco, A. - EbAnista, L. CIPOLLARI, V.

2013 Estakhr Project - Second preliminary report of the joint Mission of the Iranian Center for Archaeological Research, the Parsa-Pasargadae Research Foundation and the Sapienza University of Rome, Italy: Vicino Oriente XVII (2013), pp. 7-20.

Di CESARe, M. - EBANista, L.

2018 The Site of the Mosque at Istakhr: M.V. FonTANA (ed.), Istakhr (Iran), 2011-2016. Historical and Archaeological Essays (Quaderni di Vicino Oriente XIII), Roma 2018, pp. 251-302.

EBANISTA, L.

2018 Appendix - Stratigraphic Analysis of the Excavation Contexts: M.V. FonTANA (ed.), Istakhr (Iran), 2011-2016. Historical and Archaeological Essays (Quaderni di Vicino FONTANA, M.V. Oriente XIII), Roma 2018 pp. 316-344.

2013 Estakhr Archaeological Project. 2012 Seasons: Fondation Max van Berchem Bulletin 27 (2013), pp. 3-4.

FONTANA, M.V. (ed.)

2018 Istakhr (Iran), 2011-2016. Historical and Archaeological Essays (Quaderni di Vicino Oriente XIII), Roma 2018.

Fontana, M.V. - Asadi, A.A. - Rugiadi, M. - Felici, A.C. - Fusaro, A. - Mancini, S.

2016 Estakhr Project - Third Preliminary Report of the Joint Mission of the Iranian Center for Archaeological Research, the Parsa-Pasargadae Research Foundation and the Sapienza University of Rome, Italy: Vicino Oriente, XX (2016), pp. 75-98.

Fontana, M.V. - Mireskandari, S.M. - Rugiadi, M. - Asadi, A. - JaiA, A.M. - Colliva, L. BLANCO, A.

2012 Estakhr Project - First Preliminary Report of the Joint Mission of the Iranian Center for Archaeological Research, the Parsa - Pasargadae Research Foundation and the Sapienza University of Rome, Italy: Vicino Oriente XVI (2012), pp. 167-180. 
FusARO, A.

2018 Opaque Glazed Wares from Istakhr: A Contribution to an Outstanding Issue: M.V. FONTANA (ed.), Istakhr (Iran), 2011-2016. Historical and Archaeological Essays (Quaderni di Vicino Oriente XIII), Roma 2018, pp. 353-368.

FusARO, A. - MANCINI, S.

2018 Excavations at Istakhr in 2012: Ceramics and Stratigraphy: M.V. FonTANA (ed.), Istakhr (Iran), 2011-2016. Historical and Archaeological Essays (Quaderni di Vicino Oriente XIII), Roma 2018, pp. 345-352.

JAIA, A.M.

2018 Excavations at Istakhr in 2012: The Test West of the Site of the Mosque: M.V: FonTANA (ed.), Istakhr (Iran), 2011-2016. Historical and Archaeological Essays (Quaderni di Vicino Oriente XIII), Roma 2018, pp. 303-315, 320-344.

RUGiADI, M. - COLLIVA, L.

2018 On the Ground. The Archaeological Site of Istakhr: M.V. FonTANA (ed.), Istakhr (Iran), 2011-2016. Historical and Archaeological Essays (Quaderni di Vicino Oriente XIII), Roma 2018, pp. 127-195.

WHITCOMB, D.

1979 The City of Istakhr and the Marvdasht Plain: D. REIMER (ed.), Akten des VII. Internationalen Kongresses für Iranische Kunst und Archäologie, München, 7.-10. September 1976 (Archäologische Mitteilungen aus Iran 67), Berlin 1979, pp. 363-370. 


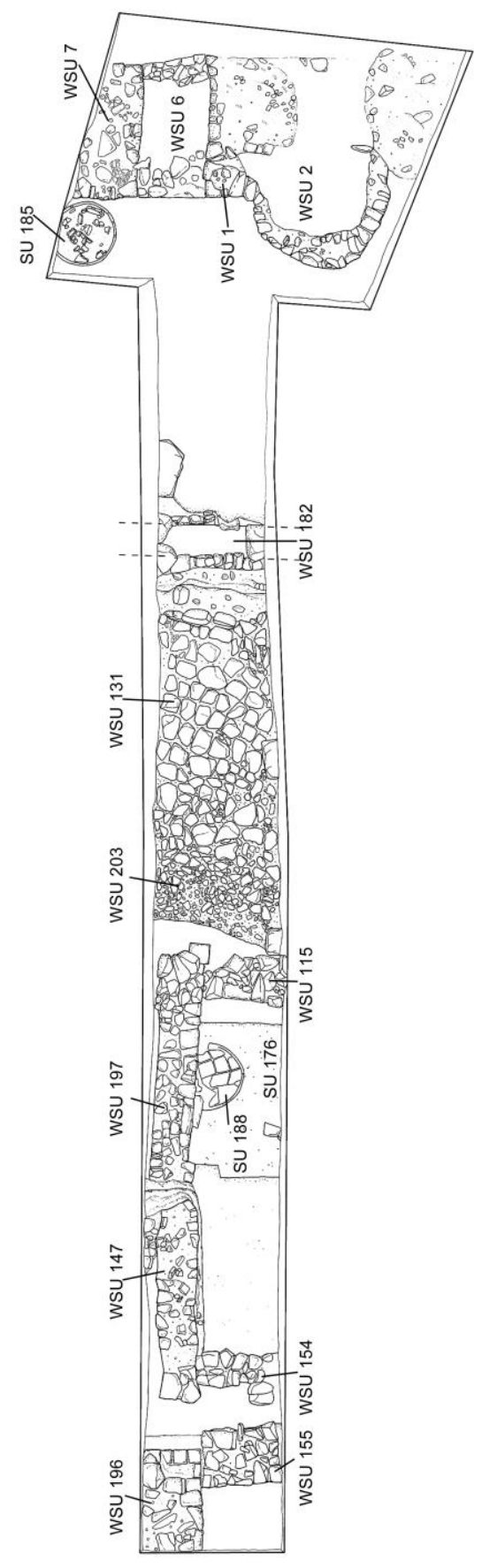




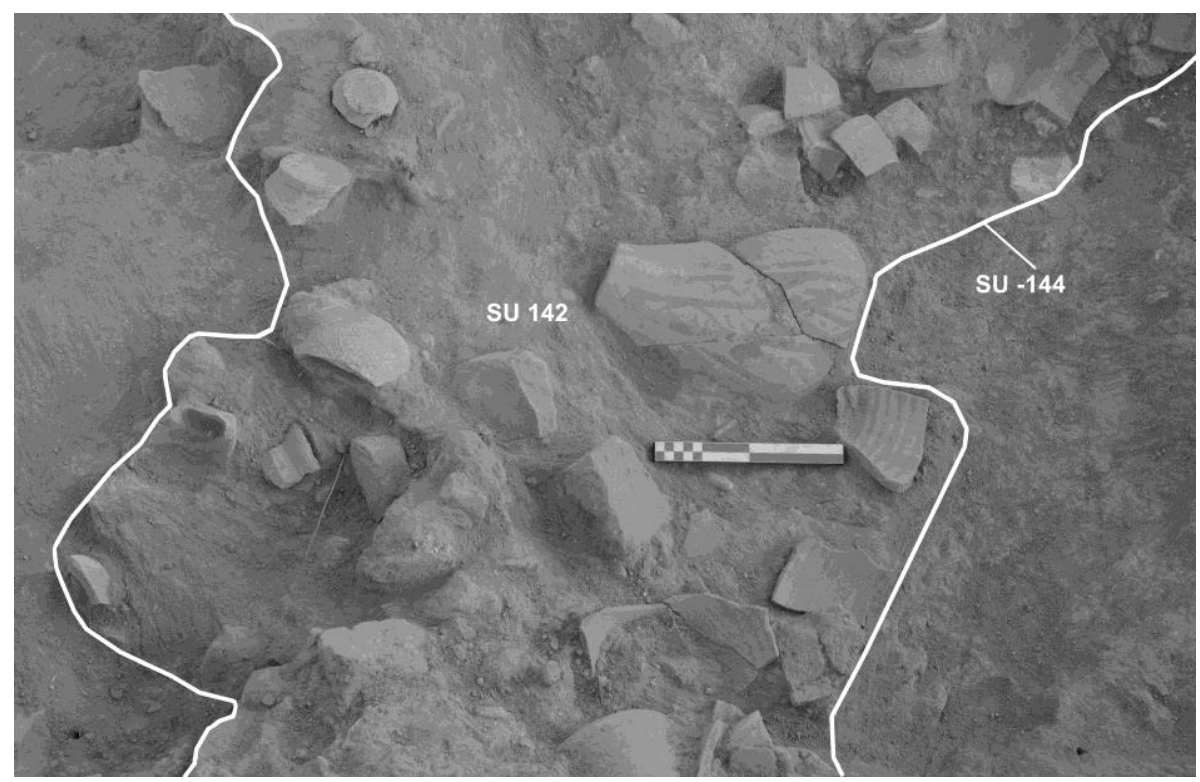

Fig. 3 - Istakhr, pottery dump SU 142, view from the north (C L. Ebanista 2012).

Fig. 4 - Istakhr, WSU 115 and 197, foundation pit of WSU 115 SU 204; the stone slab inserted into the wall WSU 115 (a) similar to the slabs used to narrow the street (b), view from the north (@) L. Ebanista 2012).

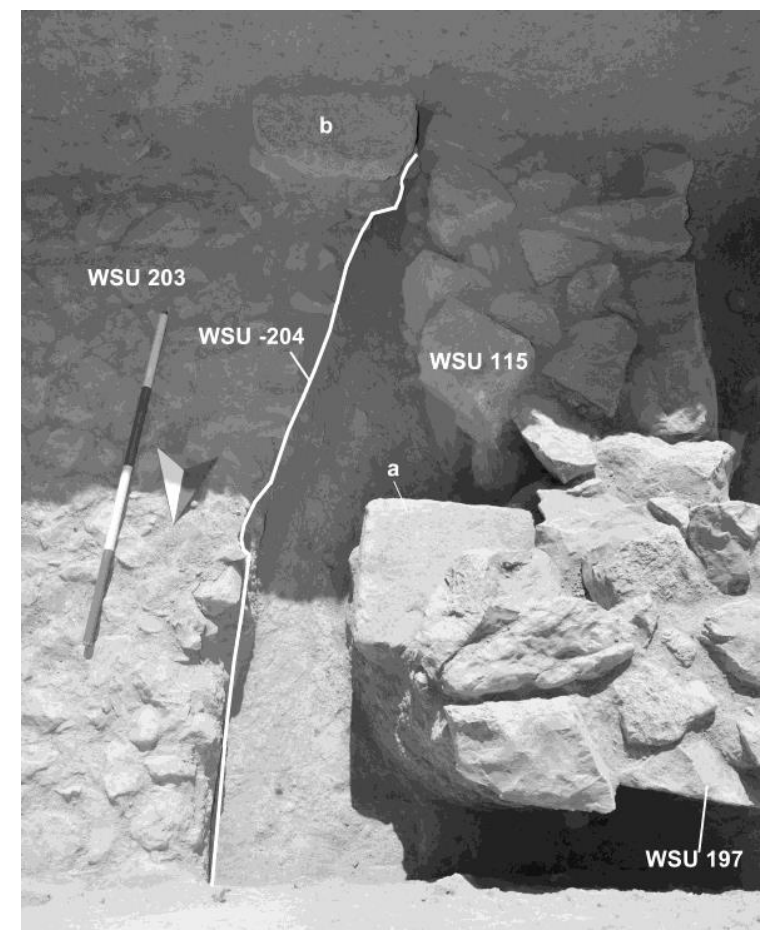




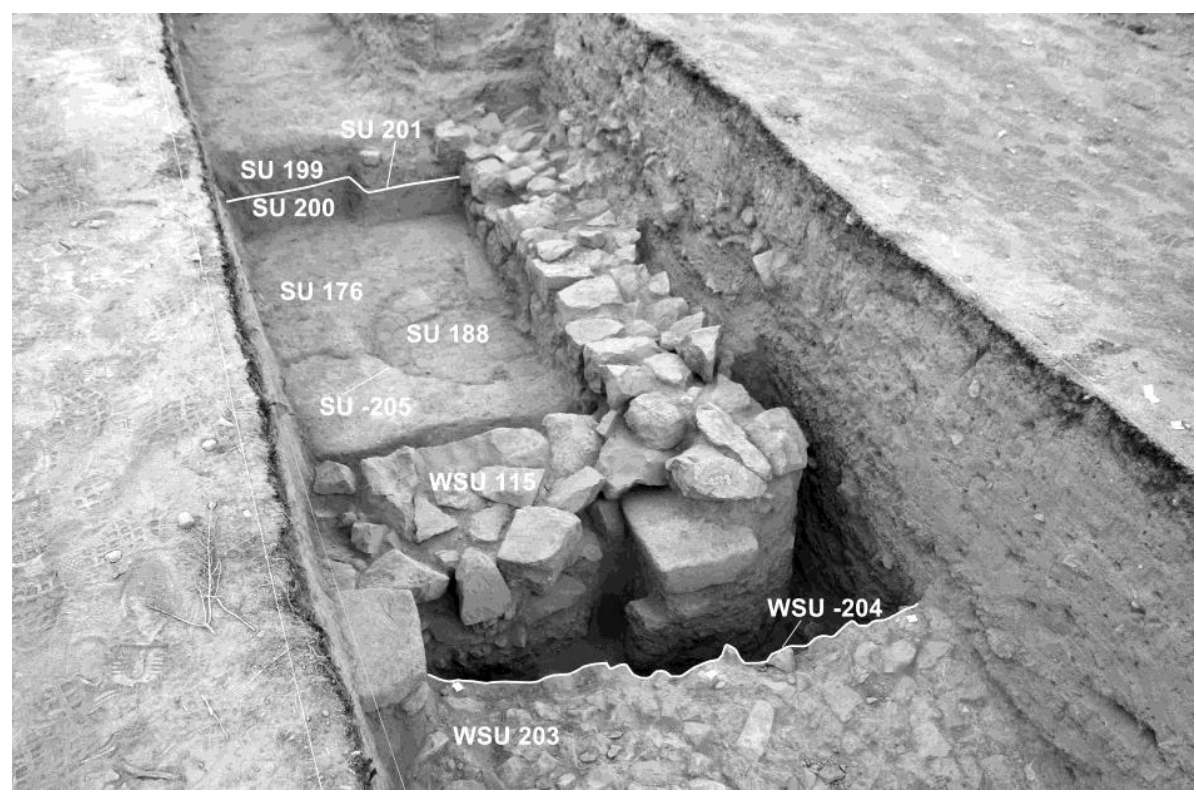

Fig. 5 - Istakhr, central area of the trench with the floor SU 176 and the tannür SU 188, view from the south-west (C) A. Blanco 2012).

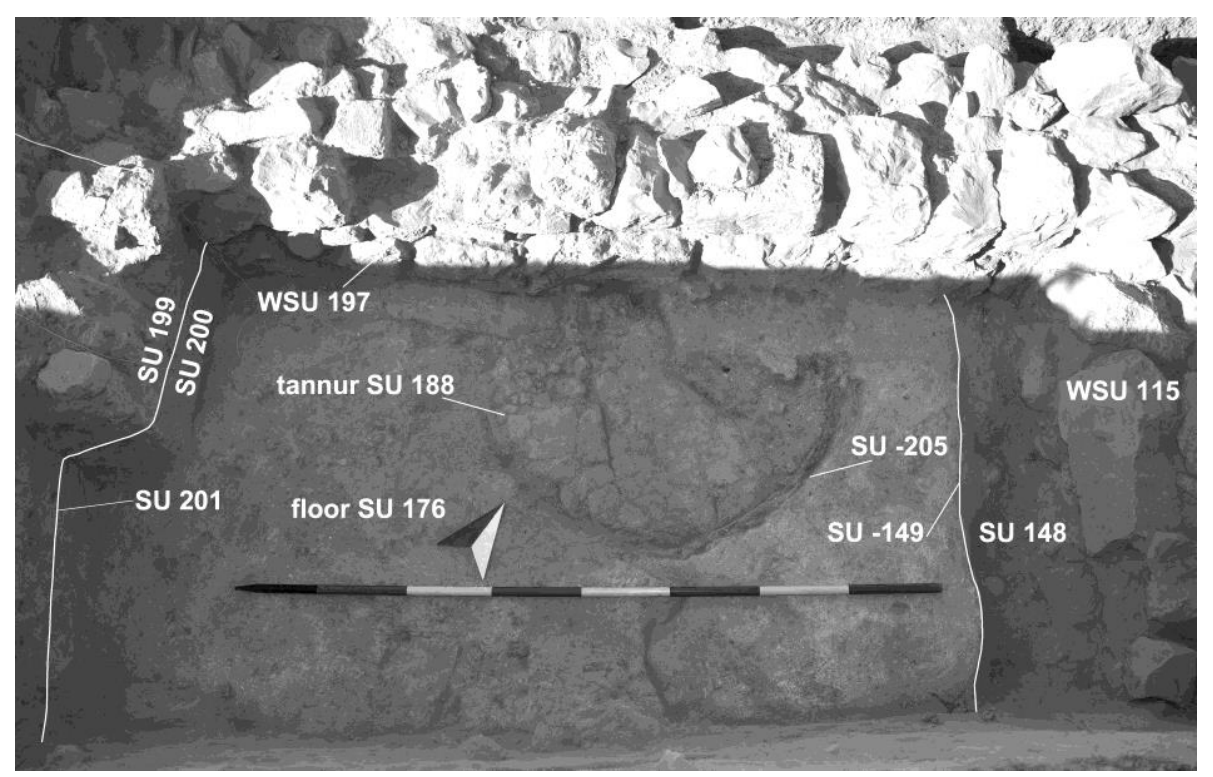

Fig. 6 - Istakhr, the ground floor SU 176 with the tannūr SU 188 (photo A. Blanco 2012, rendering L. Ebanista 2017). 


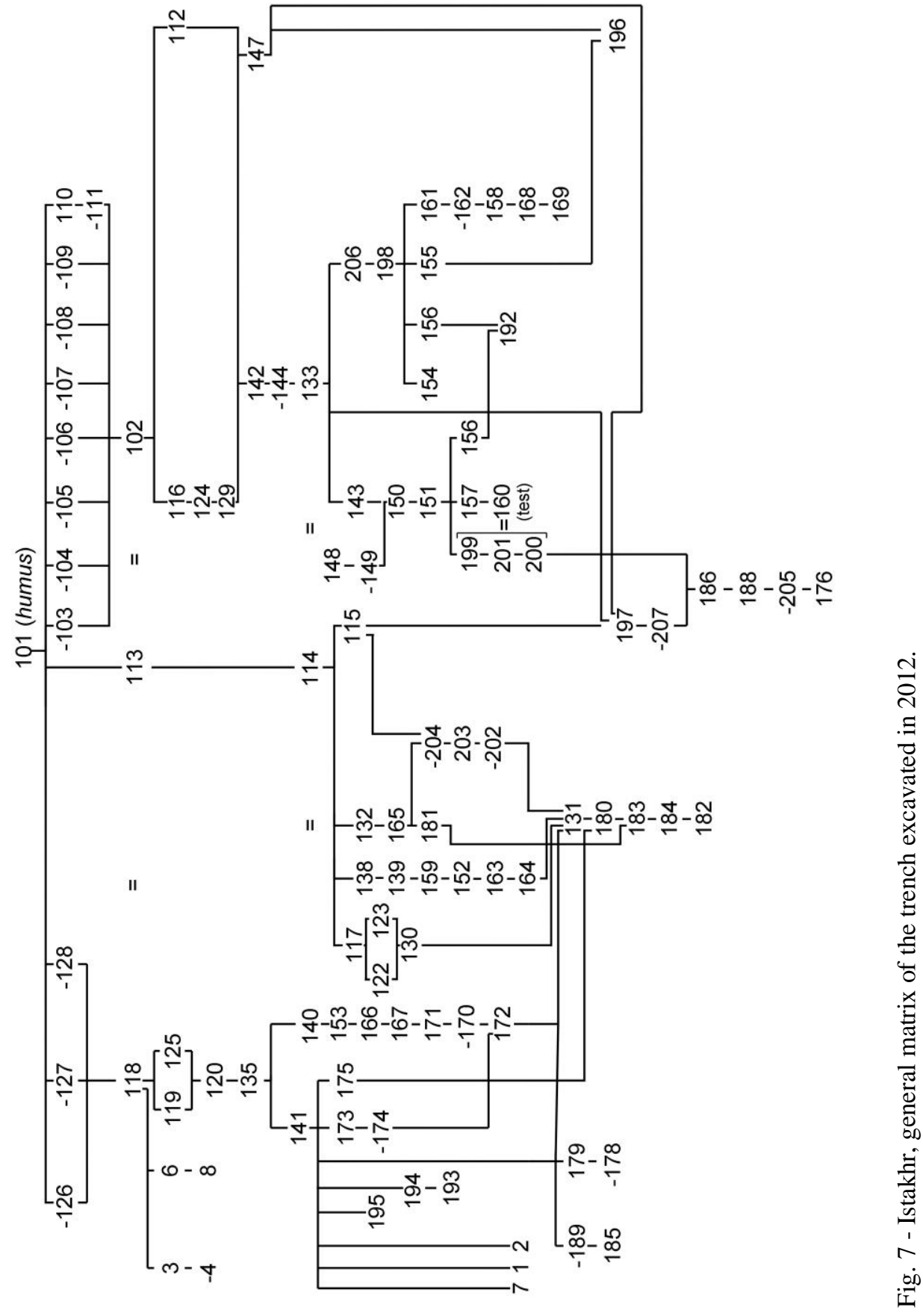

